\title{
$\mathrm{AHP}$ 기법을 활용한 인텔리전트 생존보호체계 생존성 결정인자 상대적 중요도 결정 연구 \\ 김태양 ${ }^{1)} \cdot$ 김주희 $\left.{ }^{*}, 1\right)$ \\ 1) 육군사관학교 기계·시스템공학과
}

\section{A Study on the Relative Importance of Survivability Determinant in the Intelligent Warrior Platform by Using AHP Method}

\author{
Taeyang $\mathrm{Kim}^{1)} \cdot$ Juhee $\left.\mathrm{Kim}^{*}, 1\right)$ \\ ${ }^{1)}$ Department of Mechanical and Systems Engineering, Korea Military Academy, Republic of Korea
}

(Received 5 January 2021 / Revised 16 March 2021 / Accepted 29 March 2021)

\begin{abstract}
The intelligent control algorithm based on the real-time biological monitoring system has been emphasized to enhance the survivability of the combat warrior in the future combat fields. In this study, AHP(Analytic Hierarchy Process) method was deployed to categorize the factors related to the improvement of survivability, then to determine the relative importances between them. As the details of the research process, the historical survivability determinants were firstly categorized, which was nextly judged their relative importance by the experts in the actual fileds through the survey of AHP. In this process, the consistency of the survey was investigated to filter out the error. As a result, the global priority of factors can be acquired to establish the optimized operational concepts in the intelligent warrior platform.
\end{abstract}

Key Words : Intelligent Warrior Platform(인텔리전트 워리어 플랫폼), AHP(계층적 의사결정법), Survivability Determinant(생존성 결정인자), Relative Importance(상대적 중요도)

\section{1. 서 론}

미래 전장의 첨단화된 네트워크 중심 작전에서 부 대 및 병력의 감축은 보다 정예화된 전투원을 요구하 고 있으며, 인간 중시 사상의 증대로 인해 생명을 보

\footnotetext{
${ }^{*}$ Corresponding author, E-mail: kjh6452@kma.ac.kr Copyright (c) The Korea Institute of Military Science and Technology
}

호하기 위한 생존성이 강조되고 있다[1].

따라서 전투원의 전투효율성과 생존성 증대를 위하 여 작전 활동간 발생 가능한 다양한 신체적 변화와 부상으로 인한 전투원의 생체신호를 감지하여 신체 위험 예측, 응급처치, 자가치료 등의 능동적 조치를 위한 인텔리전트 생존보호체계 알고리즘의 개발이 추 진되고 있다.

미 육군은 2005년 미래 네트워크 중심전(인간 중심 
전투)에 대비하여 Future Force Warrior(FFW)를 개발하 고 있다 ${ }^{[2]} . \mathrm{FFW}$ 는 미래 전장에 효과적으로 대응하기 위해 화기, 피복, 휴대품에 이르기까지 첨단 기술을 적용하여 각개 병사의 단위무기를 체계화하고 있으며, 이 중 생체감지 시스템은 전·평시 실시간 전투원의 전반적인 건강상태를 체크하고 최적의 상태를 유지할 수 있도록 할 뿐 아니라 부상자에 대한 신속한 파악 과 응급조치를 통해 최단시간 의무지원이 가능하게 함으로써 각개전투원의 생존성을 향상시키는데 효과 적인 것으로 알려져 있다[3].

민간 부분에서도 생체신호 모니터링(Vital Sign Monitoring) 기술은 세계적인 고령화 추세 속에서 개 인 및 국가가 부담하는 의료비 지출을 절감하기 위해 미국, 일본, 유럽 등을 중심으로 활발히 연구가 진행 중이다. 생체신호 모니터링을 비롯한 스마트 헬스케어 시장은 2015년 4.9조 달러 규모에서 2020년에는 6.8조 달러 규모로 성장하리라 전망된다 ${ }^{[4]}$.

우리 육군도 저출산 고령화로 인한 병력 감축과 병 력구조 개편에 대응하고, 동시에 각개 전투원의 전투 능력을 극대화시키기 위해 개인전투체계를 워리어 플 랫폼이란 이름으로 발전시키고 있다 ${ }^{[5]}$. 개인전투체계 는 각개 병사의 치명성, 생존성, 지휘통제, 임무지속성 및 기동성 등의 능력을 극대화 하는 체계로 다양한 형태로 개선 발전되고 있다미.

이 중 생존성 향상을 위해 전장환경에서 전투원의 신체에 손상이 가해졌을 때, 생체신호를 기반으로 전 투원의 상태 및 손상정도를 실시간 자동 인식함으로 서 신속한 대응 및 조치로 생존성 향상에 기여할 수 있을 것이다. 특히, 부상자의 경우 신속한 응급처치가 생존여부를 좌우한다는 것은 여러 전투사례를 통해 알려져 있다. 따라서 각개 전투원의 부상에 따른 응급 처치 및 부상자의 상황파악이 그 무엇보다 중요하다 고 할 수 있다. 더구나 중증외상의 경우 부상을 입은 시점부터 병원에서 치료받기까지의 소요되는 시간은 전투원의 생명유지 측면에서 매우 중요한 요소임을 여러 전투 사례를 통해 알 수 있다 ${ }^{[]}$. 왜냐하면 외상 환자의 사망 시점별 유형은 총 3 가지로 외상 후 (1) 수초 수분 이내, (2) 수시간 이내, (3) 수일 수주이 내 사망이 있다 ${ }^{[8]}$. 이중 (2)번과 (3) 번의 경우 응급조 치 시간과 후송 시스템의 효율 개선을 통해 전투원의 생존성을 연장 또는 유지시킬 수 있다는 것이 전문가 들의 일반적인 의견이다. 뿐만 아니라 개발 중인 개인 전투체계의 치명성 증대는 전투원의 전투력 향상에
기여하고, 이로 인해 간접적인 생존성 증대를 유도한 다. 이러한 차원에서 개발 중인 개인전투체계의 생존 성 효과를 정량적 혹은 정성적 분석을 통해 전투효율 성을 제고하여 체계개발과정에서 운용성능 설정에 중 요한 자료로 활용될 것이다.

따라서 본 연구는 개인전투체계를 구성하는 다양한 장비 중 전투원의 생존성 향상에 미치는 기여도를 평 가하여 생존성 향상을 위한 체계개발 우선순위를 제시 하였다. 이를 위해 미래 전장 환경에서 전투원의 임무 유형 및 작전형태를 고려하여 생존성 결정인자를 식별 하고, AHP(Analytic Hierarchy Process) 기법을 통해 각 결정인자 및 세부 개인전투체계 구성품간의 상대적 중 요도를 결정하였다. 본 연구를 통해 도출된 개인전투 체계 구성품의 상대적 중요도는 차후 체계개발의 우선 순위 결정과 각개 전투원의 생존성 효과도를 결정하는 기초자료로 활용될 것이다. Fig. 1은 개발 중인 워리어 플랫폼의 생존보호체계의 운용개념을 보여주고 있다.

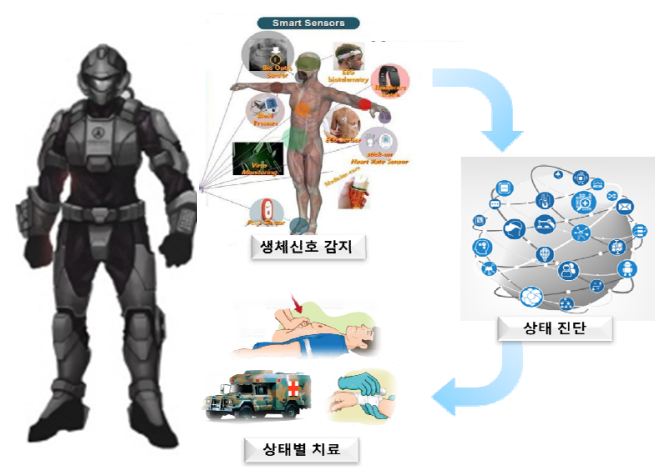

Fig. 1. Operational concept for the warrior platform ${ }^{[4]}$

\section{2. 군 의료지원체계 및 환자분류 방법 고찰}

전투상황 하에서 적의 다양한 공격으로 인해 총상 및 파편상 등의 외상환자 발생은 크게 증가하여 외과 처치 소요는 전투장비의 발달과 함께 점점 증가할 것 으로 예상된다. 대대급 이상 제대에서는 의무부대가 편제되어 군의관에 의한 응급처치 및 환자후송 등 의 무지원이 가능하지만 전투의 최소 기본제대인 중대급 이하 제대에서는 소수의 분대단위 응급처치요원과 의 무병에 의한 응급처치만 가능한 실정이다. 대대 및 연 대 구호소, 사단 치료소와 이동외과병원을 경유하여 군단지원병원, 야전군 지원병원, 후방병원으로 진단 
및 진료, 입·퇴원을 실시한다. 전문적 치료는 환자 발 생지역에서 응급처치 후 군 통제운영병원을 포함하여 후송계통 상의 군 병원 또는 가장 가까운 민간병원을 활용할 수 있다. Fig. 2에서 보는 바와 같이 최초 환 자발생지점에서는 도수운반이나 들것으로 사하지점이 나 전투근무지원대로 직접 후송하고, 연대급 이상 제 대에서는 구급차나 헬기에 의한 후송이 이루어진다 ${ }^{[8]}$.

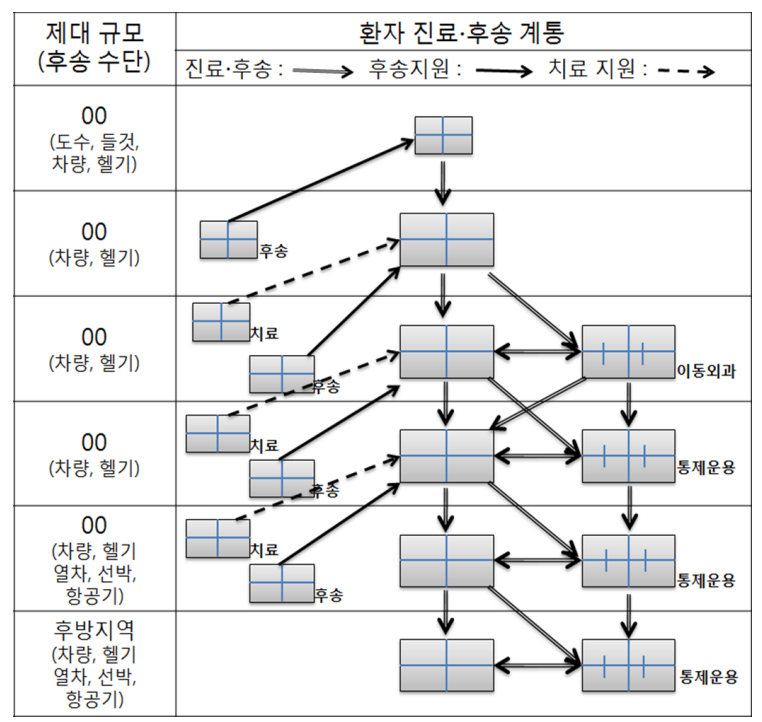

Fig. 2. Military patient services and medical support system

환자후송 시에는 기본적으로 환자의 보행가능 여부 를 판단하여 적합한 의무시실로 후송하기 위해 후송 우선순위를 설정하여 분류한다. Fig. 3에서와 같이 기 대 및 사망으로부터 긴급처치 환자, 우선처치 환자, 보통처치 환자 등 총 4 개로 구분하여 우선순위대로 후송한다. 군 환자분류에 대한 절차와 체계는 전투현 장에서 신속하게 응급처지 및 후송이 요구되는 현장 경험을 토대로 Table 1과 같이 분류된다.

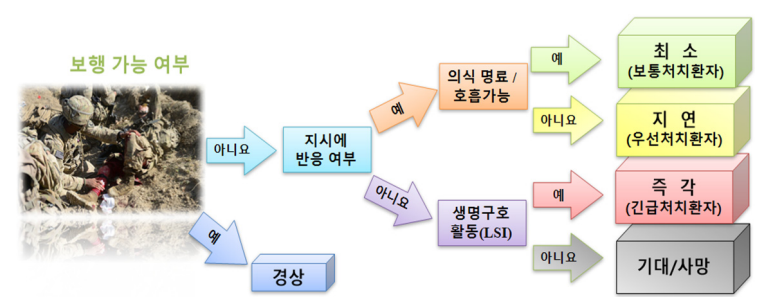

Fig. 3. Military patient classification procedure
Table 1. Main symptoms for patient classification

\begin{tabular}{|c|c|c|}
\hline 구분 & 내 용 & $\begin{array}{l}\text { 후송 } \\
\text { 기준 }\end{array}$ \\
\hline 최소 & $\begin{array}{l}\text { - 응급처치 후 임무 복귀 가능, 상황에 따라 } \\
\text { 응급처치를 보류하고 전투 임무를 우선 } \\
\text { 수행 가능 }\end{array}$ & $\begin{array}{l}24 \mathrm{H} \\
\text { 이내 }\end{array}$ \\
\hline 지연 & $\begin{array}{l}\text { - 부상을 입었어도 호흡과 의식이 양호하고 } \\
\text { 출혈에 대한 지혈이 가능하며 신체말단에 } \\
\text { 서 맥박을 촉지할 수 있음 } \\
\text { - 응급처치 후 외과적 처치가 지연되더라도 } \\
\text { 생명에 위험이 없으나, 계속 방치하면 악 } \\
\text { 화 되는 환자 }\end{array}$ & $\begin{array}{l}4 \mathrm{H} \\
\text { 이내 }\end{array}$ \\
\hline 즉각 & $\begin{array}{l}\text { - 부상이 심해 움직일 수 없고, 신체말단에 } \\
\text { 서 맥박을 관찰할 수 없음 } \\
\text { - 응급처치 및 외과적 처치가 즉시 이루어 } \\
\text { 져야 하는 환자 }\end{array}$ & 긴급 \\
\hline $\begin{array}{l}\text { 기대 } \\
\text { 사망 }\end{array}$ & $\begin{array}{l}\text { - 손상정도가 심각해 현장에 보유한 의무 } \\
\text { 물자로 소생을 기대할 수 없음 }\end{array}$ & \\
\hline
\end{tabular}

\section{3. 워리어 플랫폼 단계별 체계개발 품목}

워리어 플랫폼의 단계별 개발 품목은 Table 2에서 보는 바와 같다. 1 단계 기본요건 충족 단계에서는 생 존성 향상을 위한 방탄복, 방탄헬멧 및 조끼를 장비하 며, 치명성 향상을 위해 조준장비가 개발된다. 2단계 통합형 모델에서는 생체환경 센서가 생존성 장비로 추가되며, 주야간 조준경과 기능별 복합소총이 장비될 것이다. 3단계 일체형 모델에서는 생존보호시스템과 함께 방탄슈트, 생체인식 전투복이 각개 전투원의 생 존성을 보장할 것이다.

Table 2. Development items of Warrior platform

\begin{tabular}{|c|c|c|c|}
\hline & $\begin{array}{l}\text { 1단계 } \\
\text { 기본요건 충족 }\end{array}$ & $\begin{array}{c}\text { 2단계 } \\
\text { 통합형 모델 }\end{array}$ & $\begin{array}{c}\text { 3단계 } \\
\text { 일체형 모델 }\end{array}$ \\
\hline \multirow{2}{*}{ 생존성 } & 개별 생존체계 강화 & 모듈형 생존보호시스템 & $\begin{array}{c}\text { 일체형 } \\
\text { 생존보호시트템 }\end{array}$ \\
\hline & $\begin{array}{l}\text { 방탄복, 방탄헬ㅁㅔㅔ, 방탄조끼 } \\
\text { 방독면, 응븝처치 키트 }\end{array}$ & 생체환경 센서 & $\begin{array}{c}\text { 방탄슈트, } \\
\text { 생체인식전투복 }\end{array}$ \\
\hline \multirow[b]{2}{*}{ 치명성 } & 조준체계개선 & 조준체계개선 & 조준체계개선 \\
\hline & $\begin{array}{c}\text { 개인화기, 야간투시경, } \\
\text { 조준장비 }\end{array}$ & $\begin{array}{l}\text { 복합소총, 경기관총, } \\
\text { 주야간 조준경 }\end{array}$ & 차기소총 \\
\hline \multirow{2}{*}{ 기동성 } & 개별소형화 및 개량화 & 개별소형화, 개량화 & 개별소형화, 개량화 \\
\hline & 생존성/임무지속성 물자 & 생존성/임무지속성 물자 & 하지근력증강체계 \\
\hline \multirow{2}{*}{$\begin{array}{l}\text { 임무 } \\
\text { 지속성 }\end{array}$} & 개별전지 & 개별전지 & 개별전지 \\
\hline & $\begin{array}{c}\text { 전투피복, 수통, 개인천막, } \\
\text { 침낭, 전투조끼 }\end{array}$ & $\begin{array}{c}\text { 스마트전투복, } \\
\text { 전투조끼, 통합전원 }\end{array}$ & 미래형 전원 \\
\hline \multirow{2}{*}{$\begin{array}{l}\text { 지휘 } \\
\text { 통제 }\end{array}$} & 육성 및 육안 & 육성 및 육안 & 육성 및 육안 \\
\hline & 피아식별IR & $\begin{array}{c}\text { 정보처리기, } \\
\text { 영성전시기, 무전기 }\end{array}$ & 일체형 헬멧 \\
\hline
\end{tabular}


생존성 장비로 개발 중인 방탄헬멧/조끼 등은 신체 부위별 손상 비율을 낮춤으로써 전투원의 생존성 향 상에 기여한다. Table 3은 과학화전투훈련(KCTC)장에 서 확인된 신체부위별 부상위치에 따른 비율을 보여 준다. 이는 생존성에 대한 효과분석을 위한 기초자료 로 활용될 수 있다.

Table 3. Injury ratio of by body part(rifle)

\begin{tabular}{|c|c|c|c|c|c|}
\hline \multicolumn{2}{|c|}{ 부상위치 } & $\begin{array}{l}\text { 비율 } \\
(\%)\end{array}$ & \multicolumn{2}{|c|}{ 부상위치 } & $\begin{array}{l}\text { 비율 } \\
(\%)\end{array}$ \\
\hline \multirow{4}{*}{$\begin{array}{c}\text { 두부 } \\
(15.8 \%)\end{array}$} & 머리 & 5.8 & \multirow{3}{*}{$\begin{array}{c}\text { 흉부 } \\
(9.2 \%)\end{array}$} & 흥곽 & 4.6 \\
\hline & 눈, 귀 & 5 & & $\begin{array}{l}\text { 피부 및 } \\
\text { 피하조직 }\end{array}$ & 3.7 \\
\hline & 목 & 2.1 & & 척추 & 0.9 \\
\hline & 하관 & 5.9 & \multirow{4}{*}{$\begin{array}{c}\text { 사지 } \\
(67.5 \%)\end{array}$} & 심부근육 & 36.8 \\
\hline \multirow{4}{*}{$\begin{array}{c}\text { 복부 } \\
(5.2 \%)\end{array}$} & 복내강 & 2.8 & & 완전골절 & 12.7 \\
\hline & 흉복부 & 1.1 & & 외상성절단 & 3 \\
\hline & 복강내흥복부 & 0.6 & & 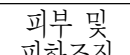 & 15 \\
\hline & $\begin{array}{l}\text { 피부 및 } \\
\text { 피하조직 }\end{array}$ & 0.7 & \multicolumn{2}{|c|}{ 기타 $(2.3 \%)$} & 2.3 \\
\hline
\end{tabular}

앞에서도 언급하였듯이 각개 전투원의 생존성 향상 은 생존체계와 직접 관련된 장비뿐아니라 상대적 전 투력 상승에 대한 효과도 고려되어야 한다. 하지만이 러한 부분까지 고려하여 생존성 효과를 정량적으로 분석하기에는 전투상황에서 발생되는 수많은 불확실 성과 가변요소(적의 전투력, 기상 및 기후조건 등)들 이 많아 현재까지 구체적인 대안이 마련되어 있지 않 다. 이러한 측면에서 본 연구에서는 $\mathrm{AHP}$ 기법을 통해 워리어 플랫폼의 모든 체계에 대한 생존성 효과에 대 한 상대적 가중치를 결정하여 향후 전투효과분석모델 의 적용 방안을 도출하고자 한다.

\section{4. $\mathrm{AHP}$ 를 활용한 우선순위 결정}

$\mathrm{AHP}$ 기법은 두뇌가 단계적 또는 위계적 분석과정 을 활용한다는 사실에 착안하여 Thomas L. Saaty 교수 가 고안한 계산모델이다 ${ }^{[9]}$. $\mathrm{AHP}$ 는 '의사결정의 목표 또는 평가기준이 다수이며 복합적인 경우, 이를 계층 화(Hierarchy)하여, 주요 요인과 그 주요 요인을 이루 는 세부 요인들로 분해하고, 이러한 요인들을 쌍대비 교(Pair-wise comparison)를 통해 중요도를 산출하는 분 석방법' 이다. 직관적으로 '다수의 속성들을 계층적으
로 분류하여 각 속성의 중요도를 파악함으로써 최적 대안을 선정하는 기법'으로 정의할 수 있다. $\mathrm{AHP}$ 는 의사결정 요소들의 속성과 그 측정 척도가 다양한 다 기준 의사결정문제에 효과적으로 적용되어 의사결정 자가 선택할 수 있는 여러 가지 대안들을 체계적으로 순위화 시키고, 그 가중치(Weight)를 비율척도(Ratio scale)로 도출하는 방법을 제시한다 ${ }^{[10]}$.

본 연구에서는 개인전투체계의 생존성 지표 도출을 위해 개인전투체계 전력화 우선순위를 고려하여 특수 임무수행 3 개 부대의 군전문가(특수작전 간부) 50 여명 을 대상으로 설문조사를 실시하였다. 가장 치열한 전 투에 노출되는 특전사 000 특수임무부대와 보병여단 특공대대, 그리고 최신화된 장비로 과학화된 훈련체계 를 담당하는 $\mathrm{KCTC}$ 전투원에 대한 의견을 수렴하여 종합하였다.

\section{1 개 요}

연구의 목표는 개인 전투원의 생존성을 결정짓는 개인전투체계 구성품의 상대적 중요도를 분석하는 것 이다. 이를 위해 먼저 개인전투체계 구성품의 시대별 생존성 레벨을 전쟁사와 각종 전투사례집을 통해 정 립하고, 워리어 플랫폼 장비의 기술수준을 분석하여 결정인자를 선정하였다. 결정인자 선정을 위해서 기존 연구 ${ }^{[1]}$ 에서 제시된 개인전투체계의 주요 장비분류와 전투효과를 결정하는 주요 결정인자를 참고하였다. 선 정된 결정인자는 $\mathrm{AHP}$ 기법을 통해 각 구성요소별 생 존성에 대한 상대적 가중치를 결정함으로써 생존성 효과 분석을 위한 정량적인 가중치 결과를 도출하는 데 있다.

평가방법으로는 우선순위 결정인자의 상대적 중요 도(가중치)를 우선 평가하고 다음으로 결정인자 별 각 무기체계의 상대적 가중치를 차례로 평가함으로써 종 합적인 중요도인 우선순위를 선정하는 것이다.

\subsection{AHP 분석절차 ${ }^{[10,12]}$}

계층적 분석 방법을 적용하기 위해서는 먼저 개인 전투체계의 각 구성요소를 식별하여 생존성에 영향을 미칠 수 있는 인자를 식별하는 것이다. 본 연구에서는 시대별로 발전되어온 개인전투체계의 일반적인 장비 특성을 고려하여 결정인자를 식별하였다. 이를 위해 전쟁사례집을 바탕으로 각개 전투원의 전투장비 구성 품을 확인하였다. Fig. 4는 세부적인 $\mathrm{AHP}$ 분석 절차 를 보여준다. 


\begin{tabular}{|c|c|c|c|c|}
\hline 1단계 & 2단계 & 3단계 & 4단계 & 5단계 \\
\hline $\begin{array}{l}\text { 계층 } \\
\text { 생성 }\end{array}$ & $\begin{array}{l}\text { 싿대비교 } \\
\text { 판단입력 }\end{array}$ & $\begin{array}{l}\text { 장대ㅇㅛㅛ적ㄷ } \\
\text { 계산 }\end{array}$ & 판단단의 & 종합중요도 \\
\hline $\begin{array}{l}\text { 시 대 별 } \\
\text { 생 존 성 } \\
\text { 결정인자 } \\
\text { 식 별 }\end{array}$ & $\begin{array}{l}\text { 상 대 적 } \\
\text { 중 요 도 } \\
\text { 비 교 } \\
\text { (의견수렴) }\end{array}$ & $\begin{array}{l}\text { 상 대 적 } \\
\text { 가 중 치 } \\
\text { 계 산 }\end{array}$ & $\begin{array}{l}\text { 가 중 치 } \\
\text { 결 과 } \\
\text { 일 관 성 } \\
\text { 검 증 }\end{array}$ & $\begin{array}{l}\text { 의견통합 } \\
\text { 및 } \\
\text { 중 요 도 }\end{array}$ \\
\hline 전쟁사 & 군 전문가 & AHP 기법 & C.I. \& C.R 계산 & 기중치 결정 \\
\hline
\end{tabular}

Fig. 4. AHP analysis process

$\mathrm{AHP}$ 분석절차를 각 단계별로 살펴보면 다음과 같 다. [1단계]에서는 의사결정을 해야 할 문제를 제시하 고 각 문제의 구성요소를 계층화하여 계층구조 트리 를 구상하는 단계이다.

계층생성의 최종 목표는 생존성을 향상시키기 위한 개인전투체계 구성품의 우선순위를 선정하는 것으로 이를 평가하기 위한 결정인자로서 생존능력에서 임무 지속능력까지 총 4개의 Lever I 결정인자를 선정하였 다. 참고로 선정된 4개의 결정인자(Determinant)는 4가 지의 전장지배능력을 의미하며, 단순히 생존능력만을 고려하는 것이 아닌 지휘통제, 기동타격, 임무지속능 력까지도 포함한다. 이는 앞서 밝힌바와 같이 개인전 투원의 생존성을 결정짓는 요소는 생존성 장비뿐만 아니라 전투력 향상이 가져다주는 간접효과도 고려하 기 위함이다. 이러한 점에서 기존의 연구들과 구분된 다고 할 수 있다.

Fig. 5는 생존성 레벨의 상대적 중요도를 결정하기 위한 계층구조 트리를 나타낸다. Level I의 하부 Level II는 각 결정인자별 개인전투 장구 및 장비를 범주화 하였다. 예를 들어 생존능력과 상응하는 하부체계로는 헬멧, 방탄복, 생체신호 감지장비 등과 같은 타격 및 지휘통제가 아닌 전투원을 보호하고 진단/치료할 수 있는 생존능력과 연관된 무기체계가 계층화되었음을 알 수 있다.

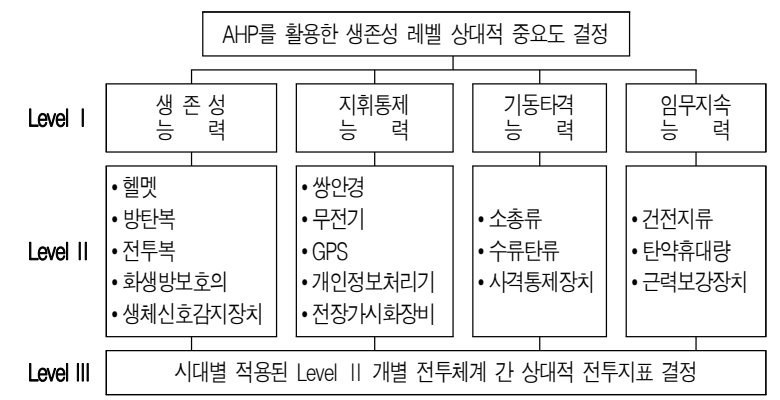

Fig. 5. Hierarchy structure tree
Table 4. $9^{\text {th }}$ multiple ratio scale

\begin{tabular}{|c|c|c|}
\hline $\begin{array}{c}\text { A요소 } \\
\text { 중요도 }\end{array}$ & 기 준 & 반대의 경우 \\
\hline 1 & $\mathrm{~A}, \mathrm{~B}$ 요소의 중요도가 비슷하다. & -1 \\
\hline 3 & A요소가 $\begin{array}{c}\text { B요소보다 더(3배) } \\
\text { 중요하다. }\end{array}$ & -3 \\
\hline 5 & $\begin{array}{c}\text { A요소가 B요소보다 조금 더(5배) } \\
\text { 중요하다. }\end{array}$ & -5 \\
\hline 7 & $\begin{array}{c}\text { A요소가 B요소보다 매우(7배) } \\
\text { 중요하다. }\end{array}$ & -7 \\
\hline 9 & $\begin{array}{c}\mathrm{A} \text { 요소가 B요소보다 } \\
\text { 절대적으로(9배) 중요하다. }\end{array}$ & -9 \\
\hline $2,4,6,8$ & 각 단계별 중간 중요도 부여 가능 & $-2,-4,-6,-8$ \\
\hline
\end{tabular}

Level III에서는 시대별로 발전되어 온 Level II 범주 의 대상 장구 및 장비들이 각각 범주화되어 비교, 평 가되었으며, 각 level 별 가중치를 고려해 개인전투체 계의 시대별 전투지표를 도출하였다.

[2단계]에서는 대안이 내포하고 있는 특징별로 결정 인자를 기준으로 각 평가요소를 $1: 1$ 로 비교하게 된다. 두 요소를 비교할 경우에 그 방법은 $\mathrm{A}$ 와 $\mathrm{B}$ 중에 어느 것이 더 중요한가? 라고 질문하게 되며, 그 중요도를 구분하는 데 사용되는 쌍대비교 척도는 일반적으로 Table 4에서 보는 바와 같이 1 에서 9 사이의 점수를 사 용하게 된다(9배수 비율척도). 참고로 $\mathrm{B}$ 가 $\mathrm{A}$ 보다 더 중요하다고 판단될 때(= 반대의 경우) 음수 부호로서 값을 입력할 것을 제시하였으며 이는 설문자의 판단 의 용이성을 제공하기 위한 하나의 수단일 뿐 실제 입력자료에는 분수로 입력되었음을 밝힌다.

Table 5는 Level I의 결정인자에 대한 전문가 집단 의 쌍대비교 결과를 기하평균으로 종합한 내용이다. 생존성 능력은 지휘통제 능력에 비해 약 1.5 배의 생존 성 기여효과가 있다는 것을 보여준다.

[3단계]에서는 쌍대비교 판단 결과값을 입력하여 수 학적 관계식 및 행렬식을 이용하여 상대적 가중치를 계산하게 된다.

Table 5. Results of calculation for weight value

\begin{tabular}{|c|c|c|c|c|}
\hline 구 분 & $\begin{array}{c}\text { 생존성 } \\
\text { 능력 }\end{array}$ & $\begin{array}{c}\text { 지휘통제 } \\
\text { 능력 }\end{array}$ & $\begin{array}{c}\text { 기동타격 } \\
\text { 능력 }\end{array}$ & $\begin{array}{c}\text { 임무지속 } \\
\text { 능력 }\end{array}$ \\
\hline 생존성 능력 & 1 & 1.499514 & 1.729571 & 1.684414 \\
\hline 지휘통제 능력 & & 1 & 0.871678 & 1.246808 \\
\hline 기동타격 능력 & & & 1 & 1.647435 \\
\hline 임무지속 능력 & & & & 1 \\
\hline
\end{tabular}




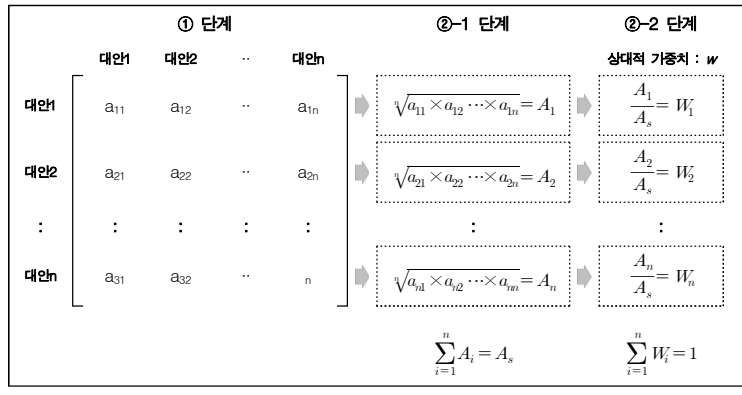

Fig. 6. Example of calculation for weight value

이 단계에서는 전문가 집단이 응답한 쌍대비교의 값을 집계하여 해당 부문별 중요도 즉 가중치를 계산 하는 것이다. 가중치 계산방법은 쌍대비교값을 정방행 렬(본 논문에서는 $3 \times 3$ 행렬로 가정)로 배열하고 이를 이용하여 대안 별 가중치를 계산한다. 세부적인 절차 및 산출 예는 Fig. 6과 같다.

(1) 설문을 통해 얻어진 상대적인 중요도 값의 기하평 균(Geometry Mean)으로 쌍대비교행렬(정방행렬)을 생성한다.

(2) 기하평균의 쌍대비교행렬로부터 다음 값을 계산하다.

(2)-1: 각 행에 대하여 $\mathrm{n}$ 개의 중요도를 곱한 후 그 값의 $\mathrm{n}$ 제곱근을 구하고 $\left(A_{i}\right)$, 합 $\left(A_{s}\right)$ 을 계산한다.

(2)-2 : (2)-1 단계에서 구한 값을 각 행에서 구한 값 들의 합 $\left(A_{s}\right)$ 으로 나누어 정규화하여 $\left(W_{i}\right)$ 를 구 한다.

이 값들은 대안 $1,2, \ldots, \mathrm{n}$ 의 상대적 가중치(Priority Vector)가 된다.

[4단계]에서는 이러한 상대적 가중치의 일관성 검증 을 위해 C.I.(Consistency Index ; 일관성지수)와 C.R. (Consistency Ratio ; 일관성비율)을 계산하여 비교한다.

이 단계에서는 대안 별 산출한 가중치를 기초로 전 체 응답자들이 신뢰성 있고 일관성 있는 응답을 하였 는지를 검증하는 단계이다. 이를 위해 AHP 기법에서는 C.R. = C.I./R.I.(일관성지수/무작위지수(Random Index)) 을 산출하여 이를 검증하게 된다. 일관성 비율 수식에 있는 R.I.는 무작위 지수를 의미하며, 1 9까지의 수를 임의로 설정하여 역수행렬을 작성하고, 이 행렬의 평 균 일관성 지수를 산출한 값으로 일관성의 허용한도 를 나타낸다. 계산 결과 C.R.값이 0.1 이내이면 쌍대비 교는 합리적인 일관성을 갖는 것으로 판단하다. 세부 적인 절차 및 산출 예는 Fig. 7과 같다.

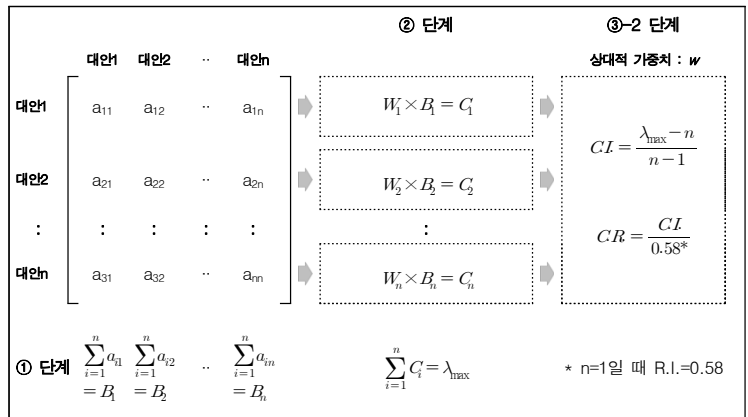

Fig. 7. Example of C.I. \& C.R. calculation

(1) 쌍대비교행렬의 각 열을 더하고 정규화된 Priority vector의 첫 성분을 첫 열의 합과 곱한다.

(2) $\mathrm{n}$ 째 열의 합에 $\mathrm{n}$ 째 Priority vector 값을 곱한다.

(3) 위의 결과를 모두 더한 값을 $\lambda_{\max }$ 정한다.

- Consistency Index(C.I.) $=\left(\lambda_{\max }-n\right) /(n-1)$

- Consistency Ratio(C.R.) = C.I./R.I.

Table 6은 Level I의 결정인자에 대한 전문가 집단 의 쌍대비교 설문 결과를 바탕으로 상대적 가중치 및 일관성 검증 결과를 보여준다. 특히 쌍대비교 시 기하 평균을 적용한 관계로 가중치의 합은 산술평균 결과 와 다를 수 있다. 이는 Level II 단계에 대한 상대비교 결과를 포함하고 있다. Table 7은 생존성 능력의 Level II 가중치 분석 결과를 보여준다. 이러한 과정에서 다 수의 비일관성 답변에 대한 결과는 제외시켰다. 상대 적 가중치는 생존성 능력 결정인자의 가중치가 전체 의 $44 \%$ 를 차지하고 있음을 보여준다 $(1$ 군단 특공 군 전문가 설문결과).

Table 6. Results of relative weight value for determinants

\begin{tabular}{|c|c|c|c|c|c|}
\hline 구 분 & $\begin{array}{l}\text { 생존성 } \\
\text { 능력 }\end{array}$ & $\begin{array}{c}\text { 지휘통제 } \\
\text { 능력 }\end{array}$ & $\begin{array}{c}\text { 기동타격 } \\
\text { 능력 }\end{array}$ & \begin{tabular}{|c|} 
임무지속 \\
능력
\end{tabular} & 가중치 \\
\hline $\begin{array}{l}\text { 생존성 } \\
\text { 능력 }\end{array}$ & 1 & 1.499514 & 1.729571 & 1.684414 & 0.439 \\
\hline $\begin{array}{c}\text { 지휘통제 } \\
\text { 능력 }\end{array}$ & & 1 & 0.871678 & 1.246808 & 0.183 \\
\hline $\begin{array}{c}\text { 기동타격 } \\
\text { 능력 }\end{array}$ & & & 1 & 1.647435 & 0.122 \\
\hline $\begin{array}{c}\text { 임무지속 } \\
\text { 능력 }\end{array}$ & & & & 1 & 0.143 \\
\hline C.I./C.R. & \multicolumn{5}{|c|}{$0.0103 / 0.0083<0.1:$ 일관성(신뢰성) 인정 } \\
\hline
\end{tabular}


Table 7. Results of relative weight value for determinants of survivability

\begin{tabular}{|c|c|c|c|c|c|c|}
\hline 구 분 & $\begin{array}{c}\text { 방탄 } \\
\text { 핼멧 }\end{array}$ & $\begin{array}{c}\text { 방탄 } \\
\text { 복 }\end{array}$ & $\begin{array}{c}\text { 전투 } \\
\text { 복 }\end{array}$ & $\begin{array}{c}\text { 화생방 } \\
\text { 보호장비 }\end{array}$ & $\begin{array}{c}\text { 생체신호 } \\
\text { 감지센서 }\end{array}$ & 가충치 \\
\hline 방탄헬멧 & 1 & 1.6445 & 1.5065 & 3.2189 & 3.4937 & 0.3430 \\
\hline 방탄복 & & 1 & 1.5738 & 2.3167 & 3.8267 & 0.2704 \\
\hline 전투복 & & & 1 & 1.2922 & 1.8840 & 0.1772 \\
\hline $\begin{array}{c}\text { 화생방 } \\
\text { 보호장비 }\end{array}$ & & & 1 & 2.0379 & 0.1292 \\
\hline $\begin{array}{l}\text { 생체신호 } \\
\text { 감지센서 }\end{array}$ & & & & 1 & 0.0802 \\
\hline C.I./C.R. & \multicolumn{7}{|c|}{$0.0173 / 0.0154<0.1:$ 일관성(신뢰성) 인정 } \\
\hline
\end{tabular}

[5단계]에서는 일관성 검증이 이상이 없다고 판단되 면, 결정인자의 가중치와 결정인자 별 대안의 상대적 가중치를 종합하여 종합중요도, 즉 우선순위를 도출한 다. Table 8 은 도출된 우선순위 결과를 보여준다.

$\mathrm{AHP}$ 기법의 마지막 단계로서 계층구조 트리를 토 대로 한 결정인자 및 결정인자별 대안의 가중치를 종 합하여 최종적인 우선순위를 도출하는 단계이다. 세부 적인 절차 및 산출 예는 Fig. 8과 같다.

(1) 결정인자별 대안의 Priority vector(가중치)를 열벡터 로 입력하고 행렬을 생성한다.

(2) 결정인자의 Priority vector를 열벡터로 하여 둘을 곱한다.

(3) 두 행렬을 곱한 결과값는 Global Priority(종합중요 도)가 되며, 대안의 우선순위는 $W_{G i}$ 크기 순으로 결정된다.

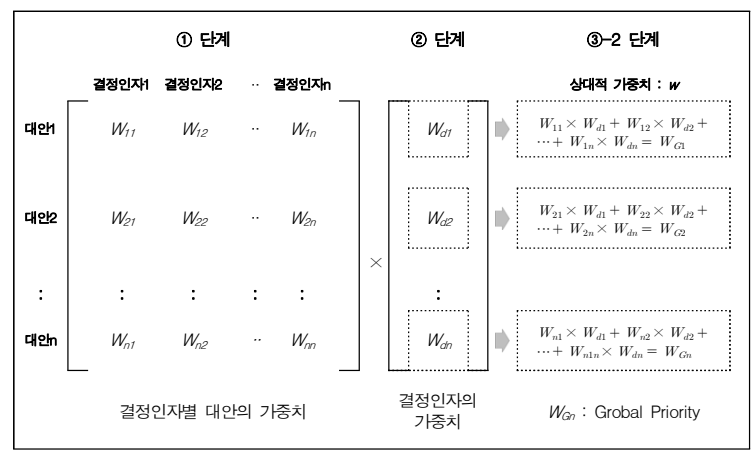

Fig. 8. Example of global priority calculation
Table 8. Global priority of weapon systems

\begin{tabular}{|c|c|c|c|c|}
\hline Level I & \multicolumn{2}{|c|}{ Level II } & 최종가중치평균 & 순위 \\
\hline \multirow{14}{*}{$\begin{array}{l}\text { 생존능력 } \\
(0.439)\end{array}$} & \multirow{3}{*}{ 헬멧 } & 철모 & 0.00981 & 22 \\
\hline & & 방탄(구) & 0.02769 & 5 \\
\hline & & 방탄(신) & 0.05975 & 1 \\
\hline & \multirow{3}{*}{ 방탄복 } & 방탄판 & 0.00919 & 24 \\
\hline & & 케블라 & 0.02436 & 8 \\
\hline & & 인터셉터 & 0.05777 & 2 \\
\hline & \multirow{3}{*}{ 전투복 } & 민무늬 & 0.00704 & 29 \\
\hline & & 위장 & 0.02147 & 13 \\
\hline & & 디지털 & 0.03176 & 3 \\
\hline & \multirow{3}{*}{$\begin{array}{l}\text { 화생방 } \\
\text { 보호의 }\end{array}$} & 방독면 & 0.00599 & 36 \\
\hline & & MOPP4 & 0.00958 & 23 \\
\hline & & 일체 & 0.02835 & 4 \\
\hline & \multirow{2}{*}{$\begin{array}{l}\text { 생체신호 } \\
\text { 감지장비 }\end{array}$} & 유 & 0.02414 & 9 \\
\hline & & 무 & 0.01277 & 20 \\
\hline \multirow{8}{*}{$\begin{array}{c}\text { 기동타격 } \\
\text { 능력 } \\
(0.122)\end{array}$} & \multirow{4}{*}{ 소총류 } & M1 & 0.00307 & 39 \\
\hline & & M16 & 0.00633 & 33 \\
\hline & & $\mathrm{K} 1$ & 0.01760 & 15 \\
\hline & & 복합 & 0.02068 & 14 \\
\hline & \multirow{2}{*}{ 수류탄 } & 충격신관 & 0.00513 & 37 \\
\hline & & 지연신관 & 0.01206 & 21 \\
\hline & \multirow{2}{*}{$\begin{array}{c}\text { 사격통제 } \\
\text { 장치 }\end{array}$} & 유 & 0.01394 & 18 \\
\hline & & 무 & 0.00765 & 26 \\
\hline \multirow{12}{*}{$\begin{array}{c}\text { 지휘통제 } \\
\text { 능력 } \\
(0.183)\end{array}$} & \multirow{2}{*}{ 쌍안경 } & 저배율 & 0.00209 & 42 \\
\hline & & 고배율 & 0.00602 & 35 \\
\hline & \multirow{4}{*}{ 무전기 } & P-6 & 0.00242 & 40 \\
\hline & & 전술무전기 & 0.00499 & 38 \\
\hline & & 소형무전기 & 0.00898 & 25 \\
\hline & & TICN & 0.02195 & 12 \\
\hline & \multirow{2}{*}{ GPS } & 유 & 0.02205 & 11 \\
\hline & & 무 & 0.00647 & 32 \\
\hline & \multirow{2}{*}{$\begin{array}{c}\text { 개인정보 } \\
\text { 처리기 }\end{array}$} & 유 & 0.01540 & 17 \\
\hline & & 무 & 0.00606 & 34 \\
\hline & \multirow{2}{*}{$\begin{array}{l}\text { 전장 } \\
\text { 가시화 }\end{array}$} & 유 & 0.02502 & 6 \\
\hline & & 무 & 0.00763 & 27 \\
\hline \multirow{8}{*}{$\begin{array}{c}\text { 임무지속 } \\
\text { 능력 } \\
(0.143)\end{array}$} & \multirow{3}{*}{ 건전지 } & 일반 & 0.00239 & 41 \\
\hline & & 초소형 & 0.00655 & 31 \\
\hline & & 통합전원 & 0.01320 & 19 \\
\hline & \multirow{3}{*}{$\begin{array}{l}\text { 탄약 } \\
\text { 휴대량 }\end{array}$} & 100 & 0.00673 & 30 \\
\hline & & 140 & 0.01680 & 16 \\
\hline & & $140+20$ & 0.02457 & 7 \\
\hline & \multirow{2}{*}{$\begin{array}{l}\text { 근력보강 } \\
\text { 장치 }\end{array}$} & 유 & 0.02305 & 10 \\
\hline & & 무 & 0.00727 & 28 \\
\hline
\end{tabular}




\subsection{AHP 설문 결과 분석}

평가기준이 될 결정인자 4가지(전장 지배능력)에 대 한 쌍대비교 설문 값을 토대로 결정인자간 상대적 가 중치를 계산하고 평가에 대한 일관성을 검증하였다. 다음으로 계층구조 트리를 바탕으로 결정인자 별 대안 (16개 무기체계, 42 개 주요장비)의 상대적 가중치를 산 정하고 그 일관성을 검증하였다. 특수부대 설문자(간 부급 50 여명)를 대상으로 한 결과는 Table 9 와 같다.

결과적으로 생존성을 극대화하기 위한 결정인자 중 생존능력 $(0.439) \rightarrow$ 지휘통제 $(0.183) \rightarrow$ 임무지속 $(0.143)$ $\rightarrow$ 기동타격능력(0.122) 순으로 가중치가 책정되었으 며, 그로 인해 생존능력 하부 대안요소인 (신)방탄헬 멧(1위), 인터셉터 방탄복(2위), 디지털 전투복(3위), 일 체형 화생방 보호의(4위) 등의 무기체계가 상위권(12 위권 $(30 \%)$ 이내)에 포진되었다. 기동타격능력 분야에 서는 상위권에 선정된 무기체계가 없는 것으로 설문 결과 나타났다. 기동타격능력으로 인한 생존성 향상 능력이 낮게 판단된 원인으로는 중량증가에 대한 부 담감이 그 원인이라 판단된다.

또한 인텔리전트 생존보호체계(생체신호, 전장가시 화, 일체형보호의, 근력보강장치)에 대한 높은 순위가 부여된 것을 확인할 수 있었다. 이는 현재 개발 중인 생존보호체계 장비에 대한 소요군의 호감도를 반영한 다고 판단할 수 있다.

\section{4 임무 제대별 $\mathrm{AHP}$ 결과 분석}

개인전투체계의 생존성 Level 상대적 중요도 분석을 위한 설문은 전·평시 특수임무를 고려하여 3 개 제대를 대상으로 분석하였다. Table 9는 특수작전부대(000 특 수임무단) 간부를 대상으로 분석된 결과 값이다. 제대 별 임무와 특성이 결과 값에 미치는 영향을 확인하기 위하여 군단 특공연대, $\mathrm{KCTC}$ 대항군 연대 간부를 대 상으로 추가적인 의견수렴을 실시하였다. 소요군의 3 개 제대, 총 150 여명의 전문가 집단을 대상으로 평가 항목(개인전투체계 개별 장비 및 장치)에 대한 상대적 중요도를 쌍대비교 방법으로 수행하였으며, 그 결과 값은 제대 임무에 따라 특정 장비에 대한 의존도가 높을 경우 우선순위에 영향을 미친다는 것을 확인할 수 있었다. 특수임부작전을 수행하는 특수전 부대 및 특공 연대의 경우 기동타격 관련 구성품의 경량화와 기동능력 향상을 위한 근력보강장치에 대해 높은 가 중치를 부여하였다. $\mathrm{KCTC}$ 대항군 연대의 경우 생존 능력 향상을 위한 보호장비 및체계에 대한 높은 선호
Table 9. Global priority by combat echelon

\begin{tabular}{|c|c|c|c|c|c|}
\hline Level I & \multicolumn{2}{|c|}{ Level II } & 707 & 1군단 & KCTC \\
\hline \multirow{14}{*}{ 생 종 } & \multirow{3}{*}{ 헬멧 } & 철모 & 28 & 22 & 20 \\
\hline & & 방탄(구) & 10 & 5 & 6 \\
\hline & & 방탄(신) & 2 & 1 & 2 \\
\hline & \multirow{3}{*}{ 방탄복 } & 방탄판 & 14 & 24 & 23 \\
\hline & & 케블라 & 4 & 8 & 8 \\
\hline & & 인터셉터 & 1 & 2 & 1 \\
\hline & \multirow{3}{*}{ 전투복 } & 민무늬 & 25 & 29 & 37 \\
\hline & & 위장 & 8 & 13 & 18 \\
\hline & & 디지털 & 3 & 3 & 11 \\
\hline & \multirow{3}{*}{$\begin{array}{l}\text { 화생방 } \\
\text { 보호의 }\end{array}$} & 방독면 & 24 & 36 & 31 \\
\hline & & MOPP4 & 26 & 23 & 21 \\
\hline & & 일체 & 17 & 4 & 9 \\
\hline & \multirow{2}{*}{$\begin{array}{l}\text { 생체신호 } \\
\text { 감지장비 }\end{array}$} & 유 & 11 & 9 & 7 \\
\hline & & 무 & 18 & 20 & 33 \\
\hline \multirow{8}{*}{$\begin{array}{l}\text { 기 동 } \\
\text { 타 격 } \\
\text { 능 력 }\end{array}$} & \multirow{4}{*}{ 소총류 } & M1 & 31 & 39 & 39 \\
\hline & & M16 & 15 & 33 & 32 \\
\hline & & $\mathrm{K} 1$ & 5 & 15 & 17 \\
\hline & & 복합 & 6 & 14 & 13 \\
\hline & \multirow{2}{*}{ 수류탄 } & 충격신관 & 19 & 37 & 25 \\
\hline & & 지연신관 & 16 & 21 & 15 \\
\hline & \multirow{2}{*}{$\begin{array}{c}\text { 사격통제 } \\
\text { 장치 }\end{array}$} & 유 & 12 & 18 & 10 \\
\hline & & 무 & 29 & 26 & 29 \\
\hline \multirow{12}{*}{$\begin{array}{l}\text { 지 휘 } \\
\text { 통 제 } \\
\text { 능 력 }\end{array}$} & \multirow{2}{*}{ 쌍안경 } & 저배율 & 41 & 42 & 41 \\
\hline & & 고배율 & 33 & 35 & 30 \\
\hline & \multirow{4}{*}{ 무전기 } & P-6 & 40 & 40 & 40 \\
\hline & & 전술무전기 & 34 & 38 & 34 \\
\hline & & 소형무전기 & 21 & 25 & 19 \\
\hline & & TICN & 13 & 12 & 12 \\
\hline & \multirow{2}{*}{ GPS } & 유 & 7 & 11 & 3 \\
\hline & & 무 & 38 & 32 & 26 \\
\hline & \multirow{2}{*}{$\begin{array}{l}\text { 개인정보 } \\
\text { 처리기 }\end{array}$} & 유 & 37 & 17 & 14 \\
\hline & & 무 & 42 & 34 & 36 \\
\hline & \multirow{2}{*}{$\begin{array}{l}\text { 전장 } \\
\text { 가시화 }\end{array}$} & 유 & 30 & 6 & 4 \\
\hline & & 무 & 36 & 27 & 28 \\
\hline \multirow{8}{*}{$\begin{array}{l}\text { 임 무 } \\
\text { 지 속 } \\
\text { 능 력 }\end{array}$} & \multirow{3}{*}{ 건전지 } & 일반 & 39 & 41 & 42 \\
\hline & & 초소형 & 22 & 31 & 35 \\
\hline & & 통합전원 & 35 & 19 & 22 \\
\hline & \multirow{3}{*}{$\begin{array}{c}\text { 탄약 } \\
\text { 휴대량 }\end{array}$} & 100 & 32 & 30 & 38 \\
\hline & & 140 & 9 & 16 & 24 \\
\hline & & $140+20$ & 20 & 7 & 16 \\
\hline & \multirow{2}{*}{$\begin{array}{l}\text { 근력보강 } \\
\text { 장치 }\end{array}$} & 유 & 23 & 10 & 5 \\
\hline & & 무 & 27 & 28 & 27 \\
\hline
\end{tabular}


$\mathrm{AHP}$ 기법을 활용한 인텔리전트 생존보호체계 생존성 결정인자 상대적 중요도 결정 연구

Table 10. Relative effectiveness on the survivability in the different warfares

\begin{tabular}{|c|c|c|c|c|c|c|}
\hline \multicolumn{2}{|c|}{ Level } & 1 & 2 & 3 & 4 & 5 \\
\hline \multicolumn{2}{|c|}{ 시기/주요전쟁 } & $\begin{array}{c}\text { 한국전쟁 이전 } \\
\text { (1940 50년대) }\end{array}$ & $\begin{array}{c}\text { 베트남 } \\
\text { (1970-80년대) }\end{array}$ & $\begin{array}{c}\text { 이라크전, } \\
\text { 미 아프간 침공 } \\
\text { (1990 2000년대) }\end{array}$ & $\begin{array}{c}\text { 현재 } \\
\text { (2010년대) }\end{array}$ & $\begin{array}{c}\text { 미래 } \\
\text { (개발 후) }\end{array}$ \\
\hline \multirow{4}{*}{$\begin{array}{l}\text { 개인 } \\
\text { 전투 } \\
\text { 체계 }\end{array}$} & 생존능력 & $\begin{array}{l}\text { • 철모 } \\
\text { •방탄판 } \\
\text { • 전투복(민무늬) } \\
\text { • 방독면 } \\
\text { • 생체신호감지(무) }\end{array}$ & $\begin{array}{l}\text { • 방탄모(구) } \\
\text { • 방탄판 } \\
\text { • 전투복(민무늬) } \\
\text { • 방독면 } \\
\text { • 생체신호감지(무) }\end{array}$ & $\begin{array}{l}\text { • 방탄모(구) } \\
\text { • 방탄복(케블라) } \\
\text { • 전투복(위장) } \\
\text { • MOPP 4단계 } \\
\text { • 생체신호감지(무) }\end{array}$ & $\begin{array}{l}\text { - 방탄모(구) } \\
\text { - 방탄복(인터셉터) } \\
\text { - 전투복(디지털) } \\
\text { - MOPP 4단계 } \\
\text { - 생체신호감지(무) }\end{array}$ & $\begin{array}{l}\text { - 방탄모(신) } \\
\text { - 방탄복(인터셉터) } \\
\text { • 전투복(디지털) } \\
\text { - MOPP 4단계 } \\
\text { (일체형) } \\
\text { - 생체신호감지(유) }\end{array}$ \\
\hline & $\begin{array}{c}\text { 지휘통제 } \\
\text { 능력 }\end{array}$ & $\begin{array}{l}\text { - 쌍안경(저배율) } \\
\text { - 무전기(P-6) } \\
\text { - GPS(무) } \\
\text { - 개인정보처리기(무) } \\
\text { - 전장가시화(무) }\end{array}$ & $\begin{array}{l}\text { - 쌍안경(저배율) } \\
\text { - 전술무전기 } \\
\text { - GPS(무) } \\
\text { - 개인정보처리기(무) } \\
\text { - 전장가시화(무) }\end{array}$ & $\begin{array}{l}\text { • 쌍안경(저배율) } \\
\text { • 소형무전기 } \\
\text { • } \mathrm{GPS}(\text { 유) } \\
\text { • 개인정보처리기(무) } \\
\text { • 전장가시화(무) }\end{array}$ & $\begin{array}{l}\text { - 쌍안경(중배율) } \\
\text { - TICN } \\
\text { • } \mathrm{GPS}(\text { 유) } \\
\text { - 개인정보처리기(무) } \\
\text { - 전장가시화(무) }\end{array}$ & $\begin{array}{l}\text { - 쌍안경(중배율) } \\
\text { - TICN } \\
\text { - } \mathrm{GPS}(\text { 유) } \\
\text { - 개인정보처리기(유) } \\
\text { - 전장가시화(유) }\end{array}$ \\
\hline & $\begin{array}{l}\text { 기동타격 } \\
\text { 능력 }\end{array}$ & $\begin{array}{l}\text { •M1,M2소총 } \\
\text { • 수류탄(충격신관) } \\
\text { • 사격통제장치(무) }\end{array}$ & $\begin{array}{l}\text { • M16 } \\
\text { - 수류탄(지연신관) } \\
\text { - 사격통제장치(무) }\end{array}$ & $\begin{array}{l}\text { • K1, K2 } \\
\text { - 수류탄(지연신관) } \\
\text { - 사격통제장치(무) }\end{array}$ & $\begin{array}{l}\text { • K1, K2 } \\
\text { - 수류탄(지연신관) } \\
\text { • 사격통제장치(무) } \\
\text { (조준경 추가) }\end{array}$ & $\begin{array}{l}\text { • 복합소총 } \\
\text { • 수류탄(지연신관) } \\
\text { • 사격통제장치(유) }\end{array}$ \\
\hline & $\begin{array}{l}\text { 임무지속 } \\
\text { 능력 }\end{array}$ & $\begin{array}{l}\text { • 일반 배터리 } \\
\text { - 개인휴대 } 100 \text { 발 } \\
\text { • 근력보강장치(무) }\end{array}$ & $\begin{array}{l}\text { • 일반 배터리 } \\
\text { - 개인휴대 } 140 \text { 발 } \\
\text { • 근력보강장치(무) }\end{array}$ & $\begin{array}{l}\text { • 초소형 배터리 } \\
\text { • 개인휴대 } 140 \text { 발 } \\
\text { • 근력보강장치(무) }\end{array}$ & $\begin{array}{l}\text { • 통합전원 } \\
\text { • 개인휴대 } 140 \text { 발 } \\
\text { - 근력보강장치(무) }\end{array}$ & $\begin{array}{l}\text { • 통합전원 } \\
\text { • 개인휴대 } \\
140 \text { 발+20(유탄) } \\
\text { • 근력보강장치(유) }\end{array}$ \\
\hline \multicolumn{2}{|c|}{000 특임대 } & 0.115 & 0.152 & 0.233 & 0.331 & 0.373(13 \% 향상) \\
\hline \multicolumn{2}{|c|}{ 00군단 특공 } & 0.102 & 0.142 & 0.211 & 0.271 & $0.399(47 \%$ 향상 $)$ \\
\hline \multicolumn{2}{|c|}{ KCTC 0000} & 0.095 & 0.131 & 0.196 & 0.253 & $0.407(61 \%$ 향상 $)$ \\
\hline \multicolumn{2}{|c|}{ 평 균 } & 0.104 & 0.142 & 0.213 & 0.285 & 0.393(38 \% 향상) \\
\hline
\end{tabular}

도를 부여하였다. 하지만 생존성 향상이라는 본질적인 효과를 반영할 수 있는 일반적인 선호도는 큰 차이가 없었다. 즉, 생존성과 직접 관련된 인터셉터, 방탄헬 멧, 생체신호장비 등이 모든 설문 집단에서 선호도 상 위에 분포하고 있었다. 따라서 개인전투체계 장비 및 장치의 일부 항목을 제외하면 부대임무와 특성이 생 존성 관련 장비의 우선순위에 미치는 영향은 미미한 것으로 판단할 수 있다.

\section{5 시대별 개인전투체계 중요도 분석}

$\mathrm{AHP}$ 기법을 통해 도출된 각 무기체계 별 상대적 가중치 값을 토대로 시대별 운용되어 온 무기체계를
구분하고 각각의 무기체계에 상응하는 가중치 값을 산술적으로 합하여 개인전투체계 적용 하에서의 상대 적인 효과도를 분석하였다. Table 10은 현대전에서 주 요한 전쟁을 기준으로 전장기능별 사용되어진 무기체 계를 나타내고 있으며, 맨 아래 행에는 시대별 각 무 기체계의 개별 가중치를 바탕으로 개인전투체계의 가 중치 합을 보여준다. 이 결과를 바탕으로 개발 중인 개인전투체계가 미래전에 적용 시 현재 운용 중인 무 기체계에 비해 평균 $38 \%$ 의 생존성의 증대를 기대할 수 있을 것으로 예상할 수 있다. Table에서 보는 바와 같이 설문 조사 대상(전투제대)에 따라 결과값은 다소 차이가 발생하는 것은 주어진 임무와 부대의 특성이 
반영된 것으로 판단된다.

이상에서 살펴본 개인전투체계 생존성 Level의 상대 적 가중치는 각개 전투원의 전투력 향상과 생존성 향 상에 기여하는 체계개발 우선순위를 결정하는데 참고 가 될 것이다.

\section{5. 결 론}

본 연구를 통해 미래 전장 환경에서 전투원의 임무 유형 및 작전형태를 고려한 인텔리전트 생존보호체계 생존성 결정인자를 식별하고 $\mathrm{AHP}$ 기법을 이용하여 각각의 결정인자 및 하부 체계의 장비 및 장치의 상 대적 중요도를 도출하였다.

그 결과 현재 개발 중인 인텔리전트 생존보호체계 에 대한 높은 가중치가 확인되었고, 이는 소요군의 관 점에서 생존성 증대를 통한 각개 전투원의 전투력 향 상에도 기여할 것으로 판단할 수 있다. 또한 시대별 개인전투체계의 생존성 효과의 가중치를 계산함으로 써 시대별 개인전투체계의 발전 양상을 확인할 수 있 었으며, 이러한 결과는 전투효과도 분석 모델(AWAM) 의 인원피해확률 범주를 변경하는데 기준을 제공함으 로써 생존성 효과도 분석의 기본 지침을 제공할 것으 로 판단한다. 하지만 개인전투체계 구성품 상호 전투 력 호환 및 보완적 측면은 객관적으로 상호연관성을 정량화가 어렵다는 측면과 응답자(전문가)에 대한 답 변의 객관성도 설문의 취지와 목적에 따라 편향될 수 도 있음을 밝힌다. 향후 다양한 부대를 대상으로 조사 대상을 확대한다면 보다 객관적인 분석이 가능할 것 으로 판단된다.

\section{후 기}

본 연구는 2021년 화랑대연구소 국고지원으로 수행 된 연구임(No. 21-군학-2).

\section{References}

[1] B. Yoon, "A Master Plan for National Defense Reformation(Revision Version 1)," The Korea Defense Daily, 2017.

[2] Brandler, P., "The United States Army Future Force Warrior-An Integrated Human Centric System," Massachusetts, pp. KN1-KN12, 2005.

[3] Friedl, K., "Real-Time Physiological Status Monitoring (RT-PSM): Accomplishments, Requirements and Research Roadmap," US Army Research Institute of Environmental Medicine, Massachusetts, pp. 1-68, 2016.

[4] Se-Han, Park, "Latest Trends in IoT-based Healthcare Platform Development," Korea Institute of Science and Technology Information, 2017, http://www.hellot. net/new_hellot/magazine/magazine_read.html?code= $202 \&$ sub $=003 \& i d x=36525$ (accessed, August 23, 2019)

[5] H. Moon, "Intelligent Warrior Platform: Enhancement of Army Power," Financial News, 2018.

[6] J. Jong and J. Gye, "Aspect a Future War and Development Direction of Weapon-System," Institute of Control, Robotics and Systems, Vol. 11, 2012.

[7] Holcomb JB, Understanding Combat Casualty Care Statistics, Journal of Trauma, Vol. 60, No. 2, pp. 397-401, 2006.

[8] Field Manual, "Medical Support," Army Headquarters pp. 35-113, 2016.

[9] Y. Heo, et. al., "Improvement Plan for Patient with a Serious Illness in the Province Wound Center (Final Report)," Ajou University, pp. 1-98, 2014.

[10] Saaty, T. L. "Decision Making with the Analytic Hi Erarchy Process," Int. J. Services Sciences, Vol. 1, No. 1, pp. 83-98, 2008.

[11] Army Analysis \& Evaluation Group, "The results of Combat Effectiveness Analysis of the Warrior Platform", pp. 1-27, 2019.

[12] J. Lee, et. al., "A Study of Priority Decision for Insensitive Munitions by Using AHP Method," Journal of the KIMST, Vol. 17, No. 6, pp. 718724, 2014. 